\title{
Blastocystis hominis AND OTHER INTESTINAL PARASITES IN A COMMUNITY OF PITANGA CITY, PARANÁ STATE, BRAZIL
}

\author{
Solange Aparecida NASCIMENTO(1) \& Maria da Luz Ribeiro MOITINHO(1)
}

\begin{abstract}
SUMMARY
The objective was to estimate the prevalence of Blastocystis hominis, to evaluate the effectiveness of different techniques for its diagnosis as well as to estimate the prevalence of other intestinal parasites in the community of Campo Verde, a district of Pitanga. The work was carried out from August to October 2004. Samples of feces from children and adults were collected and submitted to the techniques of direct wet mount, flotation in zinc sulphate solution, tube sedimentation, sedimentation in formalinether and staining by Kinyoun and iron hematoxylin methods. From 181 studied individuals, 128 (70.7\%) showed protozoa and/or helminths in stool samples. The most prevalent species were Endolimax nana (33.7\%); B. hominis (26.5\%); Giardia lamblia (18.2\%); Entamoeba coli (17.1\%); Ascaris lumbricoides (16.6\%); Iodamoeba bütschlii (9.4\%); and ancylostomatidae (7.7\%). B. hominis was only identified by the techniques of direct wet mount, sedimentation in formalin-ether and staining by iron hematoxylin, though the latter was less sensitive than the other methods. The high frequency of $B$. hominis demonstrated by this study indicates the need to include laboratory techniques that enable identification of the parasite on a routine basis.
\end{abstract}

KEYWORDS: Blastocystis hominis; Intestinal parasites; Prevalence; Diagnosis.

\section{INTRODUCTION}

Intestinal parasites have a worldwide distribution, with high rates of prevalence in regions with precarious social-economic and hygiene conditions ${ }^{21}$. It is estimated that infections caused by intestinal protozoa and helminths affect 3.5 billion people around the world, causing disease in approximately 450 million people, the majority of which are children ${ }^{25}$.

In general, parasitologic investigations include the recording of protozoa or helminths that are easily diagnosed by fecal parasitologic examination. For this to be precise it should include techniques for isolating the larvae and also parasitic elements with different specific gravity $^{18}$.

However, certain parasites require specific techniques for their diagnosis, which are not always included in routine parasitologic examination. Among these species are Blastocystis hominis, about which there is much controversy regarding its systematic position ${ }^{8,26,28}$, biology, epidemiology, pathogenicity and diagnosis s $^{3,26,28}$.

B. hominis is a polymorphic parasite, which may present in vacuolar, multivacuolar, avacuolar, granular, amoeboid and cystic forms ${ }^{26,27,28}$. As other intestinal parasites, transmission occurs by fecal-oral route, although this has not been confirmed experimentally ${ }^{26,28}$. It is probable that the cystic rather than the vacuolar form, is mainly responsible for infection by $B$. hominis ${ }^{26,28}$.

The literature has reported that $B$. hominis has a worldwide distribution, mainly in developing countries where the prevalences are higher (approximately 30 to 50\%) than those observed in developed countries $^{26,28}$. Groups with lower social-economic level and standards of hygiene tend to present a higher prevalence of infection than other groups in the community. The infection does not appear to have a gender bias, but it may be influenced by the host's age and immunologic condition $^{26,28}$.

In the Brazilian literature until 1998, according to DEVERA ${ }^{11}$, there are only six articles in which $B$. hominis has been studied or merely mentioned $^{6,13,15,17,20,22}$. Likewise since then, very few studies have been published. Among these, there are two prevalence studies carried out on patients with Acquired Immunodeficiency Syndrome ${ }^{9,14}$ and one on food workers ${ }^{5}$, which showed a prevalence of $0.5 \%, 5.8 \%$ and $80.0 \%$, respectively, for $B$. hominis. In another study, a case of therapeutic success with the drug nitazoxanide in AIDS patients infected by $B$. hominis was reported by CIMERMAN et al. ${ }^{10}$. The works of AMATO NETO et al. ${ }^{3,4}$ deal particularly with the controversy related to $B$. hominis and underscore the importance of diagnosing this protozoan.

Direct microscopic examination of fecal material, with or without 
addition of Lugol's solution, has been suggested for diagnostic purposes $^{3,27,30}$. Permanent smears stained with trichrome, iron hematoxylin, Giemsa, Gram and Wright's stains have also been recommended for the diagnosis of $B$. hominis infection ${ }^{3,26}$.

Concentration methods such as zinc sulphate flotation or gravity sedimentation technique are unsuitable for concentration of B. hominis because water, as well as several other solutions, can lysate the vacuolar, multivacuolar and granular forms of the organism ${ }^{3,26}$. Techniques for concentration using formalin-ether may however be suitable because preservative liquids are used for storage and dilution of the feces.

Infection by $B$. hominis is frequently diagnosed by the finding of vacuolar forms, which are recognized by their characteristic appearance and large size ${ }^{26}$. However, cystic forms may also be present in fecal material, and in some cases may be the main or the only form of $B$. hominis observed. Because of their small diameter ( 3 to $5 \mu \mathrm{m})$ the cysts are difficult to identify and require proper training of laboratory staff for their diagnosis ${ }^{26}$ together with the application of specific techniques, such as Ficoll-Paque column centrifugation ${ }^{29}$ and culture procedures $^{27,30}$.

The objective of the present work was to estimate the prevalence of B. hominis, to analyze the efficacy of different techniques for its diagnosis and to estimate the prevalence of other intestinal parasites among the population of Campo Verde, a shantytown district in the city of Pitanga, Paraná State.

\section{MATERIAL AND METHODS}

Area and population: This work was developed in Campo Verde, a shantytown located in the suburbs of the city of Pitanga, which is in the central region of Paraná State, Brazil. The community is made up of around 80 houses, with a population of approximately 400 people. Most of the houses are built with hardboard, canvas and scrap wood. Around $30 \%$ of the community does not have electricity, running water or toilets inside their dwellings. In these cases, their water is collected from a well and they use communal toilets.

A total of 181 individuals ranging from 11 months to 71 years of age, were chosen at random from the community. The sample size was calculated according to a $50 \%$ prevalence of protozoa and/or intestinal helminths with a confidence interval of $95 \%$ and sampling error between 4 and $5 \%$. Information was provided about the objectives of the study and collection of the fecal samples was done during domiciliary visits.

The project was approved by the Ethics Committee of the State University of Maringá, and all individuals or their legal guardian signed an informed consent form.

One fecal sample from each individual was collected and forwarded to the Clinical Parasitology Laboratory of the State University of Maringá. The study was carried out from August to October 2004.

Fecal parasitologic examination: Each fecal sample was divided into three parts: one part was submitted to direct saline and direct iodine wet mounts ${ }^{2}$ and to the techniques of zinc sulphate flotation ${ }^{2}$ and tube sedimentation ${ }^{19}$; the second part was placed in buffered formalin and then submitted to formalin-ether sedimentation technique ${ }^{2}$, followed by staining of the smears using Kinyoun's technique ${ }^{7}$; and for the third one iron hematoxylin stain was carried out after fixing in Schaudinn's liquid ${ }^{2}$.

Statistical analysis: The results for prevalence of $B$. hominis associated to gender were analyzed by Chi-square test, while Student's $t$-test was applied to the prevalence data associated to age range and for comparison of the techniques. Statistical significance was set at the $5 \%$ level.

\section{RESULTS}

Out of 181 fecal samples analyzed, 128 (70.7\%) were positive for intestinal protozoa and/or helminths. Among the protozoa, the most prevalent species were Endolimax nana (33.7\%); B. hominis (26.5\%); Giardia lamblia (18.2\%); Entamoeba coli (17.1\%) and Iodamoeba bütschlii $(9.4 \%)$, with only one $(0.6 \%)$ positive sample for Cryptosporidium sp. For the helminths, the most frequent were Ascaris lumbricoides (16.6\%) and hookworm (7.7\%) (Table 1).

Table 1

Prevalence of intestinal protozoa and helminths in 181 fecal samples of children and adults in the community of Campo Verde in the city of Pitanga, PR

\begin{tabular}{lcc}
\hline Species & \multicolumn{2}{c}{ Positive samples } \\
& No. & $\%$ \\
\hline PROTOZOA & & \\
Endolimax nana & 61 & 33.7 \\
Blastocystis hominis & 48 & 26.5 \\
Giardia lamblia & 33 & 18.2 \\
Entamoeba coli & 31 & 17.1 \\
Iodamoeba bütschlii & 17 & 9.4 \\
Entamoeba histolytica/dispar & 7 & 3.9 \\
Cryptosporidium sp & 1 & 0.6 \\
HELMINTHS & & \\
Ascaris lumbricoides & 30 & 16.6 \\
Hookworms & 14 & 7.7 \\
Enterobius vermicularis & 10 & 5.5 \\
Strongyloides stercoralis & 6 & 3.3 \\
Trichuris trichiura & 5 & 2.8 \\
Hymenolepis nana & 2 & 1.1 \\
Taenia sp & 2 & 1.1 \\
\hline
\end{tabular}

In relation to $B$. hominis, $48(26.5 \%)$ of the samples were positive. The infection was most prevalent in the six to ten years of age group (Table 2). The difference in prevalence between this age range and that of 11 to 15 years and also 16 years or older was statistically significant ( $\mathrm{p}<0.05)$. According to gender, the results showed that $B$. hominis infection was more frequent in males than females (Table 2) though this difference was not statistically significant $(p>0.05)$.

Diagnosis of $B$. hominis was only possible when the fecal samples were processed by direct saline and direct iodine wet mounts, by formalin-ether sedimentation and by iron hematoxylin stain. Out of the 48 positive samples, $36(75 \%)$ were identified by direct iodine wet mount and $33(68.8 \%)$ by direct saline wet mount (Table 3$)$. 
Table 2

Prevalence of Blastocystis hominis in children and adults in the community of Campo Verde in the city of Pitanga, PR, according to age and sex

\begin{tabular}{|c|c|c|c|c|c|c|}
\hline \multirow{4}{*}{ Age range (years) } & \multicolumn{6}{|c|}{ Positive samples/examined samples } \\
\hline & \multicolumn{4}{|c|}{ Sex } & \multicolumn{2}{|c|}{ Total } \\
\hline & \multicolumn{2}{|c|}{ Male } & \multicolumn{2}{|c|}{ Female } & \multirow[b]{2}{*}{ No. } & \multirow[b]{2}{*}{$\%$} \\
\hline & No. & $\%$ & No. & $\%$ & & \\
\hline$\leq 1$ & $1 / 4$ & 25.0 & $0 / 2$ & 0.0 & $1 / 6$ & 16.7 \\
\hline 2 to 5 & $3 / 8$ & 37.5 & $6 / 17$ & 35.3 & $9 / 25$ & 36.0 \\
\hline 6 to 10 & $3 / 10$ & 30.0 & $7 / 11$ & 53.6 & $10 / 21$ & 47.6 \\
\hline 11 to 15 & $5 / 20$ & 25.0 & $1 / 10$ & 10.0 & $6 / 30$ & 20.0 \\
\hline$\geq 16$ & $10 / 29$ & 34.5 & $12 / 70$ & 17.1 & $22 / 99$ & 22.2 \\
\hline Total & $22 / 71$ & 31.0 & $26 / 110$ & 26.0 & $48 / 181$ & 26.5 \\
\hline
\end{tabular}

Table 3

Comparison of techniques for detecting Blastocystis hominis in fecal samples of children and adults in the community of Campo Verde in the city of Pitanga, PR

\begin{tabular}{|c|c|c|c|c|c|c|c|}
\hline \multicolumn{8}{|c|}{ Positive samples $(n=48)$} \\
\hline \multicolumn{2}{|c|}{ Direct iodine wet mount } & \multicolumn{2}{|c|}{ Direct saline wet mount } & \multicolumn{2}{|c|}{ Formalin-ether sedimentation } & \multicolumn{2}{|c|}{ Iron hematoxylin stain } \\
\hline No. & $\%$ & No. & $\%$ & No. & $\%$ & No. & $\%$ \\
\hline 36 & 75 & 33 & 68.8 & 34 & 70.8 & 20 & 41.7 \\
\hline
\end{tabular}

Using the technique of formalin-ether sedimentation, $34(70.8 \%)$ samples were positive against only $20(41.7 \%)$ by iron hematoxylin stain (Table 3 ). There was a statistically significant difference between iron hematoxylin stain and the other techniques $(\mathrm{p}<0.05 \%)$.

\section{DISCUSSION}

The $70.7 \%$ positivity for intestinal protozoa and/or helminths found in this study reflects the high exposure of this community to contaminated soil and to precarious hygiene habits. A lower prevalence $(52.6 \%)$ was observed in a previous study carried out in the same city and a population with comparable social-economic and hygiene conditions $^{23}$. However, the detection of infection by $B$. hominis and the association of various techniques for the diagnosis of intestinal parasites may have been responsible for the higher index observed in this study.

Except for commensal protozoa and $B$. hominis, the most frequent parasites were G. lamblia, A. lumbricoides and hookworms. These results are consistent with data in the literature, which describe these species as the most prevalent ${ }^{1,16,21}$.

Regarding $B$. hominis, the data of the present study show a high prevalence in the community of Campo Verde. The species was identified in $26.5 \%$ of the samples analyzed, which in terms of frequency was only lower than the index found for the commensal protozoa E. nana (33.7\%).

The prevalence can be considered significant, although higher rates of infection have already been found in Brazil and abroad ${ }^{12,24}$. In Brazil, indexes of $37.8 \%, 80 \%$ and $38.3 \%$ have been recorded respectively, in surveys carried out on farm residents in the city of Holambra, São Paulo ${ }^{17}$, food workers in the city of Manaus ${ }^{5}$ and schools in the city of São Paulo ${ }^{4}$.

The observation that infection by $B$. hominis was most frequent in the age range of 10 years or less contrasts with some reports in the literature that have indicated a higher prevalence in adults than in children ${ }^{26}$. According to the review carried out by STENZEL \& BOREHAM $^{26}$, there is no gender bias, although some studies have shown a slight increase in incidence among females in relation to males; in this study no statistically significant difference was found between the sexes.

We must point out, nevertheless, that the epidemiology of B. hominis is not completely understood because studies have been impaired by imprecise information and confusion about this organism. In most of the works, $B$. hominis is not mentioned in the specifications of the results obtained from surveys designed to evaluate the presence of protozoa and helminths in different populations ${ }^{3,4}$. Furthermore, many studies only indicate the presence of $B$. hominis in fecal samples if five or more organisms per magnified field or immersion field were detected $^{26}$.

Another issue observed, which unquestionably influences the epidemiologic or prevalence data is the difficulty in making the diagnosis. It is likely that the vast majority of laboratory staff are neither able to recognize and identify $B$. hominis ${ }^{3,4}$ nor are familiar with the techniques required for its diagnosis $\mathrm{s}^{3,26,27}$.

In the present study, positive samples for $B$. hominis were identified by the techniques of direct examination, formalin-ether sedimentation 
and iron hematoxylin stain, which together detected 48 (26.5\%) cases of infection. Comparative analysis of the results, however, showed no significant difference between direct iodine and direct saline wet mounts and formalin-ether sedimentation.

Iron hematoxylin stain proved to be less sensitive than the other techniques for detection of $B$. hominis, although studies found in the literature have argued that it is as effective as direct examination techniques ${ }^{3}$.

B. hominis was not found when the zinc sulphate flotation and tube sedimentation techniques were used. It is known that recent studies $^{3,26}$ do not recommend procedures that include the use of water or other diluents that may lysate the vacuolar forms of B. hominis. The finding of $B$. hominis by zinc sulphate flotation and gravity sedimentation techniques, as described by several authors, could be due to the fact that they used preservative liquids to collect or store the fecal samples ${ }^{4}$.

The high frequency of $B$. hominis reported in this and other studies in diverse populations $s^{4,5,12}$ demonstrates the necessity to include techniques in the laboratory routine that enable the detection of this parasite. Training of technicians and laboratory staff to identify this protozoan together with the development of more suitable techniques for detecting the parasite cysts would certainly contribute to a more accurate diagnosis of $B$. hominis infection.

\section{RESUMO}

\section{Blatocystis hominis e outros parasitas intestinais em comunidade da cidade de Pitanga, Paraná, Brasil}

O presente trabalho foi realizado no período de agosto a outubro de 2004 com o objetivo de se estimar a prevalência de Blastocystis hominis, avaliar a eficácia de diferentes técnicas para o seu diagnóstico assim como estimar a prevalência de outros parasitas intestinais na comunidade de Campo Verde, município de Pitanga. Amostras de fezes de crianças e adultos foram coletadas e submetidas às técnicas de exame direto, de flutuação em solução de sulfato de zinco, de sedimentação em tubo, de sedimentação em formol-éter e de coloração pelos métodos de Kinyoun e de hematoxilina férrica. Protozoários e/ou helmintos intestinais foram detectados em 128 (70,7\%) das 181 amostras de fezes analisadas. As espécies mais prevalentes foram Endolimax nana (33,7\%); B. hominis (26,5\%); Giardia lamblia (18,2\%); Entamoeba coli $(17,1 \%)$; Ascaris lumbricoides (16,6\%); Iodamoeba bütschlii $(9,4 \%)$ e ancilostomídeos $(7,7 \%)$. B. hominis foi identificado apenas pelas técnicas de exame direto, de sedimentação em formol-éter e de coloração pela hematoxilina férrica, sendo que esta última se mostrou menos sensível que às demais. A alta freqüência de $B$. hominis evidenciada por este estudo indica a necessidade de se incluir na rotina do laboratório técnicas que permitam a identificação deste parasita.

\section{REFERENCES}

1. ALBONICO, M.; CROMPTON, D.W.T. \& SAVIOLI, L. - Control strategies for human intestinal nematode infections. Advanc. Parasit., 42: 277-341, 1999.
3. AMATO NETO, V.; RODRIGUEZ ALARCON, R.S.; GAKIYA, E. et al. - Blastocistose: controvérsias e indefinições. Rev. Soc. bras. Med. trop., 36: 515-517, 2003.

4. AMATO NETO, V.; RODRIGUEZ ALARCON, R.S.; GAKIYA, E. et al. - Elevada porcentagem de blastocistose em escolares de São Paulo, SP. Rev. Soc. bras. Med. trop., 37: 354-356, 2004

5. BENETTON, M.L.F.N.; PINHEIRO, S.S.; MACHADO, P.C. et al - Prevalência parasitária em manipuladores de alimentos em feiras livres da cidade de Manaus. Rev. Soc. bras. Med. trop., 32(supl.1): 308-309, 1999.

6. BRITES, C.; BARBERINO, M.G.; BASTOS, M.A.; SÁ, M.S. \& SILVA, N. - Blastocystis hominis as a potential cause of diarrhea in AIDS patients: a report of six cases in Bahia, Brazil. Braz. J. infect. Dis., 1: 91-94, 1997.

7. CASEMORE, D.P.; ARMSTRONG, M. \& SANDS, R.L. - Laboratory diagnosis of cryptosporidiosis. J. clin. Path., 38: 1337-1341, 1985.

8. CAVALIER-SMITH, T. - A revised six-kingdom system of life. Biol. Rev., 73: 203-266, 1998.

9. CIMERMAN, S.; CIMERMAN, B. \& LEWI, D.S. - Prevalence of intestinal parasitic infections in patients with acquired immunodeficiency syndrome in Brazil. Int. J. infect. Dis., 3: 203-206, 1999.

10. CIMERMAN, S.; LADEIRA, M.C.T. \& IULIANO, W.A. - Blastocistose: nitazoxanida como nova opção terapêutica. Rev. Soc. bras. Med. trop., 36: 415-417, 2003.

11. DEVERA, R. - Blastocystis hominis: o enigma continua. Rev. Soc. bras. Med. trop., 31: 491-493, 1998.

12. DEVERA, R.; CERMEÑO, J.R.; BLANCO, Y. et al. - Prevalencia de blastocistosis y otras parasitosis intestinales en una comunidad rural del Estado Anzoátegui, Venezuela. Parasit. latinoamer., 58: 95-100, 2003.

13. GUIMARÃES, S. \& SOGAYAR, M.I.L. - Blastocystis hominis: occurrence in children and staff members of municipal day-care centers from Botucatu, São Paulo State, Brazil. Mem. Inst. Oswaldo Cruz, 88: 427-429, 1993.

14. IRMÃO, J.I. \& PASCOAL, M.C. - Chilomastix mesnili e Blastocystis hominis: enteropatógenos oportunistas em pacientes HIV/AIDS do H.C da UFPE. In: CONGRESSO BRASILEIRO DE PARASITOLOGIA, 16., 1999, Poços de Caldas, Sociedade Brasileira de Parasitologia, 1999. Anais. p. 166.

15. JONES, T.C. - Blastocystis hominis: more than 70 years of debate regarding pathogenicity! Braz. J. infect. Dis., 1: 102-104, 1997.

16. KATZ, D.E. \& TAYLOR, D.N. - Parasitic infections of the gastrointestinal tract. Gastroent. Clin. N. Amer., 30: 797-815, 2001.

17. KOBAYASHI, J.; HASEGAWA, H.; FORLI, A.A. et al. - Prevalence of intestinal parasitic infection in five farms in Holambra, São Paulo, Brazil. Rev. Inst. Med. trop. S. Paulo, 37: 13-18, 1995.

18. MOITINHO, M.L.R. - Discriminação de ovos de helmintos em gradientes de sacarose São Paulo, 1980. (Dissertação de Mestrado - Faculdade de Ciências Farmacêuticas da Universidade de São Paulo).

19. MOITINHO, M.L.R. \& FERREIRA, C.S. - Avaliação de técnica de sedimentação em tubos. Rev. Inst. Med. trop. S. Paulo, 36: 153-156, 1994.

20. MOURA, H.; FERNANDEZ, O.; VIOLA, J.P.B. et al. - Enteric parasites and HIV infection: ocurrence in AIDS patients in Rio de Janeiro, Brazil. Mem. Inst. Oswaldo Cruz, 84: 527-533, 1989.

21. ORGANIZACIÓN MUNDIAL DE LA SALUD - Prevención y control de las infecciones parasitarias intestinales. Org. Mond. Salud Ser. Inf. técn., (749), 1987.

2. AMATO NETO, V. \& CORRÊA, L.L. - Exame parasitológico de fezes. São Paulo, Sarvier, 1980. p. 47-56. 
22. PIRES DE MATOS, C.; AMATO NETO, V.; BRAZ, L.M.A. et al. - Blastocystis hominis. Diagnóstico por exame direto e por coloração com tionina. Rev. Soc. bras. Med. trop., 31(supl. 1): 188, 1998.

23. PUPULIN, A.R.T.; PAULINO, V.; MEXIA, A.P.A. et al. - Saúde em assentamentos rurais: uma questão de parcerias e política social. Rev. bras. Anal. clin., 29: 41- 44, 1997.

24. REQUENA, I.; HERNÁNDEZ, Y.; RAMSAY, M.; SALAZAR, C. \& DEVERA, R. Prevalencia de Blastocystis hominis en vendedores ambulantes de comida del municipio Caroní, Estado Bolívar, Venezuela. Cadern. Saúde públ. (Rio de J.), 19 1721-1727, 2003.

25. SCHUSTER, H. \& CHIODINI, P.L. - Parasitic infections of intestine. Curr. Opin. infect. Dis., 14: 587-591, 2001.

26. STENZEL, D.J. \& BOREHAM, P.F.L. - Blastocystis hominis revisited. Clin. Microbiol. Rev., 9: 563-584, 1996.
27. SURESH, K. \& SMITH, H. - Comparison of methods for detecting Blastocystis hominis. Europ. J. clin. Microbiol. infect. Dis., 23: 509-511, 2004.

28. TAN, K.S.W.; SINGH, M. \& YAP, E.H. - Recent advances in Blastocystis hominis research: hot spots in terra incognita. Int. J. Parasit., 32: 789-804, 2002.

29. ZAMAN, V. - Morphology of the cyst of Blastocystis hominis. Southeast Asian J. trop. Med. publ. Hlth., 25: 790-791, 1994.

30. ZMAN, V. \& KHAN, K.Z. - A comparison of direct microscopy with culture for the diagnosis of Blastocystis hominis. Southeast Asian J. trop. Med. publ. Hlth., 25: 792-793, 1994.

Received: 11 January 2005

Accepted: 23 May 2005 